\title{
Locus Interactions Underlie Seed Yield In Soybeans Resistant to Heterodera glycines
}

\author{
U.B. Karangula1,3, M.A. Kassem ${ }^{1,2}$, L. Gupta ${ }^{3}$, H. \\ A. EI-Shemy ${ }^{1,4}$ and D.A. Lightfoot ${ }^{1 *}$
}

${ }^{1}$ Plant Biotechnology and Genomics Core-Facility, Department of Plant, Soil, and Agricultural Systems, Southern Illinois University, Carbondale, IL 62901-4415, USA

2Present Address: Department of Natural Sciences, Fayetteville State University, Fayetteville, NC 283014298, USA

${ }^{3}$ Department of Electrical and Computer Engineering, Southern Illinois University, Carbondale, IL 62901-4415, USA

${ }^{4}$ Faculty of Agriculture Research Park (FARP) and Biochemistry Department, Faculty of Agriculture, University of Cairo, 12613 Giza, Egypt

Received 8 August 2008

Revised 22 September 2008

Accepted 20 October 2008

Sponsors: Institutional sponsor Office of the OVCR, SIUC. Granting Agencies ISA, USB, IMBA, NSF, and NCSRB. Publication \#2008_77 in the SIUC_PBGC series.

\begin{abstract}
In soybean (Glycine max L. Merr.) combining resistance to cyst nematode (SCN; Heterodera glycines I.) with high seed yieldremains problematic. Molecular markers linked to quantitative trait loci (QTL) have not provided a solution. Sets of markers describing a collection of favorable alleles (linkats) may assist plant breeders seeking to combine both traits. The objective of this analysis was to identify linkats in genomic regions underlying seed yield and root SCN resistance QTL. Used were groups of cultivars selected from a single recombinant inbred (RIL) population derived from 'Essex' by 'Forrest' (ExF). The yield was measured at four locations. SCN resistance was determined in greenhouse assays. The mean seed yield was used to define 3 groups (each $n=30$ ), high, medium and low. SCN resistance formed 2 groups (SCN resistant $(n=21)$ and SCN susceptible $(n=69)$ ). Microsatellite markers (213) alleles were compared with seed yield and root SCN (Hetrodera glycines) resistance using mean analysis. The number, size and position of
\end{abstract}

Abbreviations: ExF 'Essex' by 'Forrest'. Linkats, a collection of favorable alleles linked in attraction (linkats). RIL, recombinant inbred population. QTL, quantitative trait loci. SCN, soybean cyst nematode.

"For correspondence: ga4082@siu.edu Tel: (618) 453 1797. Fax: (618) 4537457. potential linkats were determined. Loci, genomic regions and linkats associated with seed yield were identified on linkage group (LG) $\mathrm{K}$ and with root resistance to $\mathrm{SCN}$ e on LGE, G, and D1b+W. A method to identify co-localized genomic regions is presented.

\section{Introduction}

Soybean [Glycine $\max$ (L.) Merr.] is one of the world's major crops (Singh and Hymowitz, 1999) grown commercially for its oil (16\%) and protein content (42\%). Seed yield has doubled over the last 30 years largely by selection of superior adapted cultivars (Specht et al., 2001). However, in the same period soybean has proven susceptible to many diseases that reduce yields. Breeders have struggled to combine high seed yield with resistance to soybean cyst nematode (SCN; caused by Heterodera glycines I.) due to linkage drag and other unknown factors (Mudge et al., 2001; Yuan et al., 2002; Concibido et al., 2004; Kopisch-Obuch et al., 2005). In contrast high seed yield has been readily combined with resistance to diseases like soybean sudden death syndrome (SDS; Hnetkovsky et al., 1996; Meksem et al., 1999; Prabhu et al., 1999; lqbal et al., 2001).

In soybean and other plant species, the majority of economically important agronomic traits like seed yield are controlled in a quantitative fashion (Mansur et al., 1993, 1996). Molecular markers have been used extensively to construct genetic and linkage maps (Song et al., 2004; Zhang et al., 2004; Kassem et al., 2006) and to identify quantitative trait loci (QTL) underlying valuable traits (Yuan et al., 2002; Kopisch-Obuch et al., 2005; Kassem et al., 2006, 2007a,b). However, simple selection of loci for SCN resistance combined with high seed yield has not eliminated the negative relationship between the traits when cyst pressure is low.

Possible explanations for the negative relationship between resistance to SCN and seed yield are sought. One possibility is that introgression of the genes for resistance to SCN has disrupted linkats, a collection of favorable alleles that are linked (Demarly, 1979). In SCN susceptible soybean cultivars large regions where recombination rarely occurs have been detected (Lorenzen et al., 1996; Stefaniak et al., 2005). However, the cultivars with the highest seed yield tend to have more than the mean number of recombination events on several linkage groups ( $22, \mathrm{~L}$ and $\mathrm{M})$. A second possibility is that the genes for resistance to SCN are themselves unfavorable to seed yield so that selection of new linkats at other genomic locations are needed to ameliorate those negative effects (Lark et al., 1995; Yuan et al., 2002). Indeed there is strong evidence that the resistance allele of major gene for resistance to SCN (rhg1) is rigidly co-inherited with an allele on linkage group $\mathrm{M}$, because embryo or pollen in-viability results from breaking this association (Webb et al., 1996). Even 
when those alleles are co-inherited negative effects on of rhg1 on plant growth and development can be observed (Yuan et al., 2002; Kopisch-Obuch et al., 2005; Ruben et al., 2006). Both the rhg1 and Rhg4 loci contain several candidate genes, but both include receptor-like kinases that appear likely to play a role in root development (Afzal and Lightfoot, 2007).

Recent studies on analysis of soybean genomes (Obermayer and Greilhuber, 1999; Brown-Guedira et al., 2000; Grant et al., 2000; Shoemaker et al., 1996, 2002; Alkharouf and Mathews, 2004; Shultz et al., 2006) showed that the genome duplicated twice and regions of conserved homeology remain (Shoemaker et al., 1996; Grant et al., 2000; Blanc and Wolfe, 2004; Choi et al., 2004; Shultz et al., 2007; Schlueter et al., 2007). The major genes for resistance to SCN on linkage groups A2 (Rhg4) and $\mathrm{G}$ (rhg1) both have 2 or more homeologous regions where conserved synteny is observed (Campbell et al., 2007; Afzal and Lightfoot, 2007). Therefore, it is likely that regions separate from the loci underlying seed yield and resistance to SCN can be affecting those trait but would escape detection by normal method of QTL map development and locus based detection of epistasis.

The objective of this study was to identify interactions between linkats and loci underlying seed yield and SCN resistance. The analysis identified significant patterns of association between alleles at 213 microsatellite DNA markers, soybean genome structures and mean yield. Prediction was made of the genome structure capable of combining yield with disease resistance.

\section{Materials and methods}

\section{Genetic material}

The genotypes used in this study were the ExF96 population described by Lightfoot et al., 2006. The marker data used was the 213 microsatellite markers from Kassem et al., (2006). Markers were arranged in map order. Trait data were as described in Yuan et al., 2002 for seed yield and in Kassem et al., 2006 for resistance to SCN Hg Type 0.

\section{Data classification}

The groups were selected by ranking the genotypes for yield and disease resistance analysis. For seed yield two equal groups of 30 genotypes with lowest yield and highest yield were used. For disease resistance two groups were defined female index reported for five plants challenged with 2000 eggs of SCN Hg type 0 (race3; Yuan et al., 2002). The two groups are resistant $(\mathrm{FI}<10)$ and susceptible (FI>10) with 21 and 69 genotypes respectively.

\section{Statistical analysis}

The ranked genotypes were used to count the number of alleles corresponding to each marker in map order. Allelic chains (multiple As or Bs) and recombination events ( $A$ juxtaposed to $B$ ) were counted. The means for each genotype corresponding to $A, A A, A A A, A A A A, A A A A A, B$, $B B, B B B, B B B B, B B B B B, B A, A B$, values were calculated. The 12 numbers obtained were then subjected to mean analysis to determine whether phenotype groups differed significantly. The number of allelic chains on each of the chromosome of the genomic structure were calculated and compared.

The mean was the sum of all the scores divided by the number of scores. The formula in summation notation is $\mu=\Sigma X / N$, where $\mu$ is the population mean and $N$ is the number of scores. Since the scores were from a sample, then the symbol $\mathrm{M}$ refers to the mean and $\mathrm{N}$ refers to the sample size. The formula for $\mathrm{M}$ is the same as the formula for $\mu$. The mean is a good measure of central tendency for roughly symmetric distributions but can be misleading in skewed distributions since it can be greatly influenced by extreme scores. Therefore, distributions were tested for normality.

\section{Results and discussion}

\section{Marker allele segregation}

The data set used was identical to that reported in Kassem et al., (2006). There were 12, 958 Forrest alleles and 12, 823 Essex alleles at all markers in the data set. That difference was not significant. Further Chi square showed no significant deviations for the expected $1: 1$ segregation ratio at any of the 240 markers used (heterogeneous scores were excluded). Therefore, segregation was not biased at any locus or across the whole data set. Recombination events showed evidence for non random distribution across linkage groups whether measure directly (not shown) or as linkats of Essex alleles (Fig. 1) or Forrest alleles (Fig. 2). Linkat and recombination frequencies were significantly different in some genotype groups and some linkage groups (see below).

\section{Correlation among traits}

SCN resistance and seed yield in non-SCN infested locations were not negatively correlated $(r=0.12, p=0.1$; Supplemental Fig. 1). The negative correlation may have been lost due to a low but significant yield loss to SCN in environments considered non-infested. Cysts were present but at less than 10 cyst per $100 \mathrm{~cm}^{3}$ of rooting soil.

\section{Disease resistance}

Linkats were found on linkage groups (LG) A2, E, D1b and $G$ that were significantly different between the SCN resistant and susceptible phenotype groups $(n=21$ and $n=69$ ) compared to the overall population distribution. There was a significant increase in the number and length of chains of Forrest alleles associated with the SCN susceptible group at LG E $(p=0.0001)$ and D1b $(p=0.01$; Supplental Table 1). Conversely, there was a significant increase in the number and length of chains of Essex alleles associated with the SCN susceptible group at LG A2 $(p=0.045)$ and $G(p=0.009)$ and a significant decrease on LG E $(p=0.0005)$ and D1b $(p=0.05$; Supplemental Table 2). Equally recombination events were depressed among the SCN resistant lines at these LGs. Compared to the population as a whole there was a significant increase in the number of recombination event at LG G and concomitant decrease in the numbers and lengths of chains of Forrest alleles associated with the 


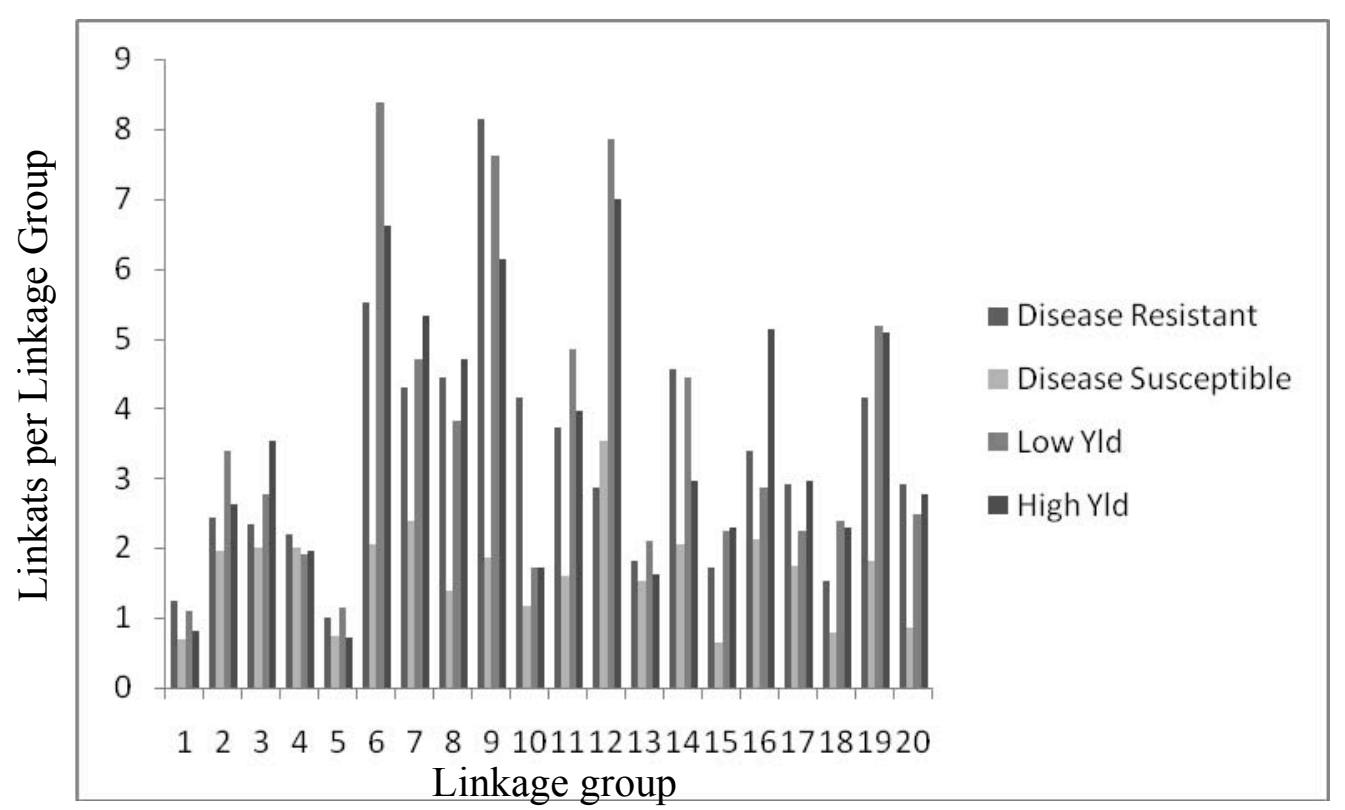

Fig. 1. Linkat distribution of Essex alleles across the 20 linkage groups of soybean within the genotype groups for high yield, low yield, resistance to SCN and susceptibility to SCN. Chromosomes are numbered 1 to 20 .

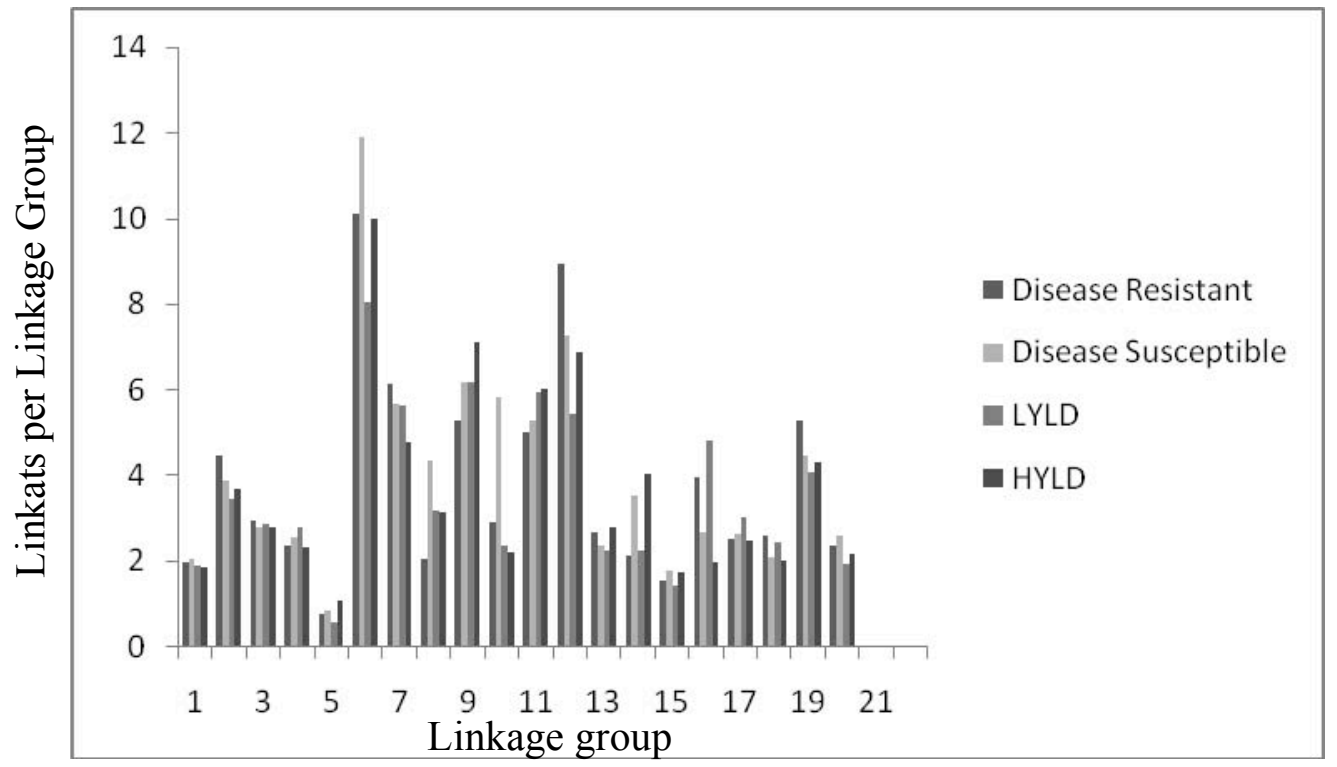

Fig. 2. Linkat distribution of Forrest alleles across the 20 linkage groups of soybean within the genotype groups for high yield, low yield, resistance to SCN and susceptibility to SCN. Chromosomes are numbered 1 to 20.

SCN resistant set. Considering only long linkats, those of more than 3 alleles, there was a significant decrease in the number and length of chains of Essex allele's as among the SCN susceptible lines on LGs A2 ( $p=0.015)$, $\mathrm{G}(p=0.0067)$, and $\mathrm{M}(p=0.029)$. Long linkats of Forrest alleles were found in the disease susceptible group on LG D1b $(p=0.012)$ and LG E $(p=0.0002)$. Overall linkats and recombination events frequencies appeared to be similar in frequency across all LG of the two phenotypic sets but not at the particular linkage groups associated with Rhg genes (A2, G and M) present in Forrest and two linkage groups not known to have effects on resistance to SCN HG Type 0 (E and D1b).

\section{Seed yield}

Linkats were found on LG I and K that were significantly different between the high yield and low yield phenotype groups $(n=30)$. There was a significant increase $(p=0.0098)$ in the number and length of chains of Essex alleles associated with the high yield group at LG K but a decrease on LG I ( $p=0.03$; Supplemental Table 3). Conversely, LG I showed a significant increase $(p=0.002)$ in the number and length of linkats of Forrest alleles and a significant decrease on LG K $(p=0.00003$; Supplemental Table 4). Longer linkats of 3 or more alleles showed a similar pattern with a significant increase $(p=0.0026)$ in the number and length of chains of Essex 
alleles associated with the high yield group at LG K but a decrease on LG I $(p=0.018)$. Also in the high yield group long linkats significantly increased on LG C1 $(p=0.026)$ and significantly decreased LG L $(p=0.03)$ Conversely, LG I showed a significant increase $(p=0.002)$ in the number and length of linkats of Forrest alleles and a significant decrease on LG K $(p=0.0003)$ for both mean and long linkats. Equally recombination events were depressed among both the high and low resistant lines at these LGs. Overall linkats and recombination events frequencies appeared similar in frequency across all LG of the two phenotypic sets except particular LG I and K previously associated with seed yield.

\section{Discussion}

Genome architecture associated with yield was detected in the ExF population. Most impressively the markers revealed a very strong linkat to QTL association between yield on genetic linkage group $\mathrm{K}$ and I. Both LGs were shown to contain QTL for seed yield (Yuan et al., 2002; Kassem et al., 2007a). In Williams by Essex there were more recombination events and smaller linkats on LG K among high yielding cultivars compared to the population as a whole (Stephaniak et al., 2005). Linkage group I did not differ in linkat size or recombination events in that study. The beneficial allele for the LG K QTL was from Essex (Yuan et al., 2002; Kassem et al., 2006; 2007a) and so the association with long linkats of Essex alleles may indicate a locus with several underlying genes distributed over a large region of the genome. Equally the beneficial allele for the LG I QTL was from Forrest (Yuan et al., 2002; Kassem et al., 2007a) and so the association with long linkats of Forrest alleles may indicate a locus with several underlying genes distributed over a large region of the genome. Several other yield QTL were detected on LG A2, C1, C2, J. and N but they were not associated with linkats or recombination frequency variation (Lark et al., 1995; Kassem etal., 2006; Guzman et al., 2007). Such loci might be underlain by single genes, small gene clusters or sets of epistatic loci.

Genome architecture was associated with SCN resistance but not only at loci known to encompass QTL (LG A2, G and M; Meksem et al., 2001; Webb et al., 1995). Linkats of Forrest alleles detected on linkage groups $E$ and $D 1 b$ in the $S C N$ susceptible group and their absence from the SCN resistant group might be related to selection for loci that ameliorate the effect of the resistance loci, like that on LG M (Webb et al., 1995). Equally the decrease in the number and length of chains of Essex alleles associated with the SCN resistant group around the QTL bearing regions of $L G A 2$ and $G$ might indicate the loci are multigenenic. However, over the entire genome linkats of Forrest alleles were not more abundant than expected.

The low incidence of polymorphism between Essex and Forrest resulted in a paucity of markers in some regions $(C 1, J)$. Gaps between markers in individual maps undoubtedly caused important linkats to be missed.. However, marker density was quite high on most of the LG reported to contain linkats here (A2, C2, G, I, K). With continued expansion of soybean yield QTL studies; additional markers need to be tested in the gaps (Shultz et al., 2007). Further studies can be made by testing the same QTL in a different population and re-examining yield QTL identified without examining the effect of linkats (Orf et al., 1999a; 1999b; Yuan et al., 2002; Kabelka et al., 2004; Smalley et al., 2004; Guzman et al., 2007).

\section{Acknowledgments}

The authors acknowledge diverse contributions toward the research reported; for funding from 1991-2004 the ISA, USB, IMBA, NSF, and NCSRB to build the map and trait data; and for assistance by Dr. O. Myers Jr., Dr. M.E. Schmidt and all members of the SIUC field teams from 1983 to 2007 . This material was also partly based on work supported by the National Science Foundation under Grant No. 9872635. Any opinions, findings, and conclusions or recommendations expressed in this material are those of the author(s) and do not necessarily reflect the views of the National Science Foundation.

\section{References}

Afzal, A.J. and Lightfoot, D.A. (2007) Inclusion bodies contain RHG1 folding intermediates, a novel refolding protocol for protein purification. Prot. Exp. Purif. 53, 346-355.

Alkharouf, N.W. and Matthews, B.F. (2004) SGMD, the Soybean Genomics and Microarray Database. Nucl. Acids Res. 32, D398-D400.

Brown-Guedira, G.L., Thompson, J.A., Nelson, R.L., and Warburton, M.L. (2000) Evaluation of genetic diversity of soybean introductions and North American ancestors Using RAPD and SSR markers. Crop Sci. 40, 815-823.

Blanc, G. and Wolfe, K.H. (2004) Widespread paleopolyploidy in model plant species inferred from age distributions of duplicate genes. Plant Cell 16, 1667-1678.

Choi, H.K., Mun, J.H., Kim, D.J., Zhu, H., Baek, J.M., Mudge, J., Roe, B., Ellis, N., Doyle, J., Kiss, G.B, Young, N.D., and Cook, D.R. (2004) Estimating genome conservation between crop and model legume species. Proc. Natl. Acad. Sci. U.S.A. 101, 15289-15294.

Concibido, V.C., Diers, B.W., and Arelli, P.R. (2004) A decade of QTL mapping for cyst nematode resistance in soybean. Crop Sci. 44, 1121-1131.

Grant, D., Cregan, P.B., and Shoemaker, R.C. (2000) Genome organization in dicots, Genome duplication in Arabidopsis and synteny between soybean and Arabidopsis. Proc. Natl. Acad. Sci. U.S.A. 97, 41684173

Guzman, P.S., Diers, B.W., Neece, D.J., Martin, S.K.S., LeRoy, A.R., Grau, C.R., Hughes, T.J., and Nelson, R.L. (2007) QTL associated with yield in three backcrossderived populations of soybean. Crop Sci. 47, 111122.

Hnetkovsky, N., Chang, S.J.C., Doubler, T.W., Gibson, P.T., and Lightfoot, D.A. (1996) Genetic mapping of loci underlying field resistance to soybean sudden death syndrome. Crop Sci. 36, 393-400.

Kopisch-Obuch, F.J., McBroom, R.L., and Diers, B.W. (2005) Association between SCN resistance loci and yield in soybean. Crop Sci. 45, 956-965. 
Kabelka, E.A., Diers, B.W., Fehr, W.R, LeRoy, A.R., Baianu, I.C., You, T., Neece, D.J., and Nelson, R.L. (2004) Putative alleles for increased yield from soybean plant introductions. Crop Sci. 44, 784-791.

Kassem, M.A., Shultz, J.L., Meksem, K., Cho, Y., Wood, A.J., Iqbal, M.J., and Lightfoot, D.A. (2006) An updated 'Essex' by 'Forrest' linkage map and first composite interval map of QTL underlying six soybean traits. Theor. Appl. Genet. 113, 1015-1026.

Kassem, M.A., Meksem, K., Wood, A.J., and Lightfoot, D.A. (2007a) Loci underlying SDS and SCN resistance mapped in the 'Essex' by 'forrest' soybean recombinant inbred lines. Rev. Biol. Biotech. 6, 2-10.

Kassem, M.A., Meksem, K., Wood, A.J., and Lightfoot, D.A. (2007b) A microsatellite map developed from late maturity germplasm 'Essex' by 'Forrest' detects four QTL for soybean seed yield expected from early maturing germplasm. Rev. Biol. Biotech. 6, 11-18.

Lark, K.G., Chase, K., Adler, F., Mansur, L.M., and Orf, J.H. (1995) Interactions between quantitative trait loci in soybean in which trait variation at one locus is conditional upon a specific allele at another. Proc. Natl. Acad. Sci. U.S.A. 92, 4656-4660.

Lightfoot, D.A., Njiti, V.N., Gibson, P.T., Kassem, M.A., lqbal, M.J., and Meksem, K. (2005) Registration of the Essex by Forrest recombinant inbred line mapping population. Crop Sci. 45, 1678-1681.

Lorenzen, L.L., and Shoemaker, R.C. (1996) Genetic relationship within old, U.S. soybean cultivar groups. Crop Sci. 36, 743-752.

Mansur, L.M., Lark, K.G., Kross, H., and Oliveira, A. (1993) Interval mapping of quantitative trait loci for reproductive, morphological, and seed traits of soybean. Theor. Appl. Genet. 86, 907-913.

Mansur, L.M., Orf, J.H., Chase, K., Jarvik, T., Cregan, P.B., and Lark, K.G. (1996) Genetic mapping of agronomic trait using recombinant inbred lines of soybean. Crop Sci. 36, 1327-1336.

Meksem, K., Doubler, T.W., Chancharoenchai, K., Njiti, V.N., Chang, S.J.C., Rao-Arelli, A.P., Cregan, P.E., Gray, L.E., Gibson, P.T., and Lightfoot, D.A. (1999) Clustering among loci underlying soybean resistance to Fusarium solani, SDS and SCN in near-isogenic lines. Theor. Appl. Genet. 99, 1131-1142.

Meksem, K., Pantazopoulos, P., Njiti, V.N., Hyten, D.L., Arelli, P.R., and Lightfoot, D.A. (2001) 'Forrest' resistance to the soybean cyst nematode is bigenic, saturation mapping of the Rhg1 and Rhg4 loci. Theor. Appl. Genet. 103, 710-717.

Obermayer, R., and Greilhuber, J. (1999) Genome size in Chinese soybean accessions - stable or variable? Ann. of Bot. 84, 259-262.

Orf, J.H., Chase, K., Jarvik, T., Mansur, L.M., Cregan, P.B., Adler, F.R., and Lark, K.G. (1999a) Genetics of soybean agronomic traits, I. Comparison of three related recombinant inbred populations. Crop Sci. 39, 1642-1651.

Orf, J.H., Chase, K., Alder, F.R., Mansur, L.M., and Lark, K.G. (1999b) Genetics of soybean agronomic traits, II. Interaction between yield quantitative trait loci in soybean. Crop Sci. 39, 1652-1657.
Ruben, E., Aziz, J., Afzal, A.J., Njiti, V.N., Triwitayakorn, K., Iqbal, M.J., Yaegashi, S., Arelli, P.R., Town, C.D., Meksem, K., and Lightfoot, D.A. (2006) Genomic analysis of the 'Peking' rhg1 locus, candidate genes that underlie soybean resistance to the cyst nematode Molec. Genet. Genom. 276, 320-330.

Schlueter, J.A., Vasylenko-Sanders, I.F., Deshpande, S., Yi, J., Siegfried, M., Rose, B.A., Schlueter, S.D., Scheffler, B.E., and Shoemaker, R.C. (2007) The FAD2 gene family of soybean, insights into the structural and functional divergence of a paleoploid genome. Crop Sci. 47 (S1), S14-S26.

Shoemaker, R.C., Polzin, K., Labate, J., Specht, J., Brummer, E.C., Olson, T., Young, N.D., Concibido, V., Wilcox, J., Tamulonis, J.P., Kochert, G., and Boerma, H.R. (1996) Genome duplication in soybean (Glycine subgenus soja). Genetics 144, 329-338.

Shoemaker, R.C., Keim, P., Vodkin, L., Retzel, E., Clifton, S.W., Waterston, R., Smoller, D., Coryell, V., Khanna, A., J. Erpelding, X. Gai, V. Brendel, C.R. Schmidt, E.G. Shoop, C.J. Vielweber, M. Schmatz, D. Pape, Y. Bowers, B. Theising, J. Martin, M. Dante, T. Wylie, and Granger, C. (2002) A compilation of soybean ESTs, generation and analysis. Genome 45, 329-338.

Shultz, J.L., Jayaraman, D., Shopinski, K.L., Iqbal, M.J., Kazi, S., Zobrist, K., Bashir, R., Yaegashi, S., Lavu, N., Afzal, A.J., Yesudas, C.R., Kassem, M.A., Wu, C., Zhang, H.B., Town, C.D., Meksem, K., and Lightfoot, D.A. (2006a) The soybean genome database (SoyGD), A browser for display of duplicated, polyploid, regions and sequence tagged sites on the integrated physical and genetic maps of Glycine max. Nucleic Acid Research 34, D1-D8.

Shultz, J.L., Yesudas, C.R., Yaegashi, S., Afzal, A.J., Kazi, S., and Lightfoot, D.A. (2006b) Three minimum tile paths from bacterial artificial chromosome libraries of the soybean (Glycine max cv 'Forrest'), Tools for structural and functional genomics. Plant Methods 2, 9-18.

Singh, R.J. and Hymowitz, T. (1999) Soybean genetic resources and crop improvement. Genome 42, 605616.

Smalley, M.D., Fehr, W.R., Cianzio, S.R., Han, F., Sebastian, S.A., and Streit, L.G. (2004) Quantitative trait loci for soybean seed yield in elite and plant introduction germplasm. Crop Sci. 44, 436-442.

Song, Q.J., Marek, L.F., Shoemaker, R.C., Lark, K.G., Concibido, V.C., Delannay, X., Specht, J.E., and Cregan, P.B. (2004) A new integrated genetic linkage map of the soybean. Theor. Appl. Genet. 109, 122-128.

SoyBase (2007) http://soybase.agron.iastate.edu/ (Last accessed 12 December 2007).

Specht, J.E., K. Chase, M. Macrander, G.L. Graef, J. Chung, J.P. Markwell, M. Germann, J.H. Orf, and, K.G. Lark (2001) Soybean response to water, A QTL analysis of drought tolerance. Crop Sci. 41, 493-509.

Stefaniak, T.R., Hyten, D.L., Pantalone, V.R., Klarer, A., and Pfeiffer, T.R. (2005) Soybean cultivars resulted from more recombination events than unselected lines in the same population. Crop Sci. 46, 43-51.

Stuber, C.W., Lincoln, S.E., Wolff, D.W, Helentjaris, T., and Lander, E.S. (1992) Identification of genetic factors 
contributing to heterosis in a hybrid from two elite maize inbred lines using molecular markers. Genetics 132, 832-839.

Webb, D.M., Baltazar, B.M., Arelli, P.R., Schupp, J., Clayton, K., Keim, P., and Beavis, W.D. (1995) Genetic mapping of soybean cyst nematode race-3 resistance loci in the soybean PI 437.654. Theor. Appl. Genet. 91, 574-581.

Yuan, J., Njiti, V.N., Meksem, K., lqbal, M.J., Triwitayakorn, K., Kassem, M.A., Davis, G.T., Schmidt,
M.E., and Lightfoot, D.A. (2002) Quantitative trait loci in two soybean recombinant inbred line populations segregating for yield and disease resistance. Crop Sci. 42, 271-277.

Zhang, W.K., Wang, Y.J, Luo, G.Z., Zhang, J.S., He, C.Y., Wu, X.L., Gai, J.Y., and Chen, S.Y. (2004) QTL mapping of ten agronomic traits on the soybean (Glycine max, L. Merr.) genetic map and their association with EST markers. Theor. Appl. Genet. 108, 1131-1139.

\section{Supplementary Material}

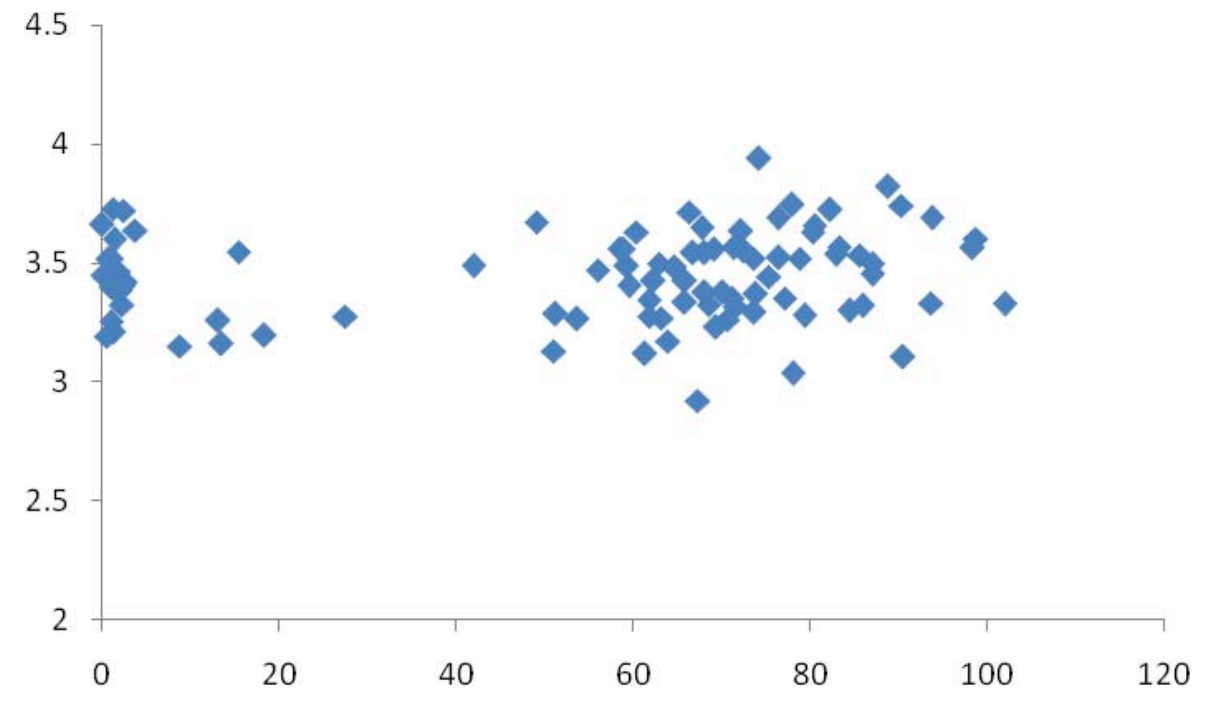

Supplemental Fig. 1. Correlation between mean seed yield in non-infested locations and resistance to SCN Hg Type 0. 
Locus Interactions Underlie Seed Yield In Soybeans Resistant to Heterodera glycines i79

Supplemental Table 1. Linkats of Forrest alleles in SCN resistant and susceptible groups.

\begin{tabular}{|c|c|c|c|c|c|}
\hline & Disease Resistant & Disease Susceptible & Ratio & Probability & Linkage Groups \\
\hline \multirow[t]{19}{*}{$B$} & 2.9048 & 3 & 0.96825 & 0.422409 & $\mathrm{~A} 1$ \\
\hline & 6.4286 & 5.6087 & 1.1462 & 0.18244 & $\mathrm{~A} 2$ \\
\hline & 5.2857 & 5.0435 & 1.048 & 0.34566 & $\mathrm{~B} 1$ \\
\hline & 4.1429 & 4.3913 & 0.94342 & 0.318569 & B2 \\
\hline & 1.381 & 1.6957 & 0.81441 & 0.151028 & C1 \\
\hline & 12.81 & 13.957 & 0.91782 & 0.256559 & C2 \\
\hline & 8.2857 & 8.0435 & 1.0301 & 0.843459 & D1a \\
\hline & 3.9524 & 5.7391 & 0.68867 & 0.03494 & $D 1 b$ \\
\hline & 7.5238 & 8.0435 & 0.93539 & 0.363385 & D2 \\
\hline & 4.3333 & 7.0435 & 0.61523 & 0.000105 & $E$ \\
\hline & 13.19 & 10.696 & 1.2333 & 0.029528 & $G$ \\
\hline & 3.9524 & 4.087 & 0.96707 & 0.39344 & $\mathrm{H}$ \\
\hline & 4.1905 & 5.5217 & 0.75891 & 0.044905 & I \\
\hline & 2.5238 & 2.4348 & 1.0366 & 0.434052 & $\mathrm{~J}$ \\
\hline & 5.6667 & 4.5217 & 1.2532 & 0.110741 & $\mathrm{~K}$ \\
\hline & 4.381 & 4.6522 & 0.9417 & 0.325899 & $\mathrm{~L}$ \\
\hline & 3.4762 & 2.913 & 1.1933 & 0.157233 & $M$ \\
\hline & 7.0952 & 6.3913 & 1.1101 & 0.258952 & $\mathrm{~N}$ \\
\hline & 3.3333 & 3.8261 & 0.87121 & 0.278682 & 0 \\
\hline \multirow[t]{18}{*}{ BB } & 2 & 2.0435 & 0.97872 & 0.469067 & $\mathrm{~A} 1$ \\
\hline & 2.381 & 2.5652 & 0.92817 & 0.384325 & B2 \\
\hline & 0.7619 & 0.86957 & 0.87619 & 0.373186 & $C 1$ \\
\hline & 10.095 & 11.913 & 0.84741 & 0.1666 & $C 2$ \\
\hline & 6.1429 & 5.6957 & 1.0785 & 0.361802 & D1a \\
\hline & 2.0476 & 4.3478 & 0.47095 & 0.01442 & $D 1 b$ \\
\hline & 5.2857 & 6.1739 & 0.85614 & 0.286717 & D2 \\
\hline & 2.9048 & 5.8261 & 0.49858 & $9.52 \mathrm{E}-05$ & $E$ \\
\hline & 5 & 5.3043 & 0.94262 & 0.379111 & $\mathrm{~F}$ \\
\hline & 8.9524 & 7.2609 & 1.233 & 0.123539 & $G$ \\
\hline & 2.6667 & 2.3913 & 1.1152 & 0.324406 & $\mathrm{H}$ \\
\hline & 2.1429 & 3.5217 & 0.60847 & 0.028879 & 1 \\
\hline & 1.5714 & 1.7826 & 0.88153 & 0.341171 & $\mathrm{~J}$ \\
\hline & 3.9524 & 2.6957 & 1.4662 & 0.093804 & $\mathrm{~K}$ \\
\hline & 2.5238 & 2.6522 & 0.9516 & 0.415432 & $L$ \\
\hline & 2.619 & 2.087 & 1.255 & 0.18487 & M \\
\hline & 5.2857 & 4.4783 & 1.1803 & 0.23432 & $\mathrm{~N}$ \\
\hline & 2.381 & 2.6087 & 0.9127 & 0.39237 & 0 \\
\hline
\end{tabular}


i80 Karangula et al.

Supplemental Table 1. Continued

\begin{tabular}{|c|c|c|c|c|c|}
\hline & Disease Resistant & Disease Susceptible & Ratio & Probability & Linkage Groups \\
\hline \multirow[t]{20}{*}{ BBB } & 1.4286 & 1.4783 & 0.96639 & 0.461257 & $\mathrm{~A} 1$ \\
\hline & 3.1905 & 2.7391 & 1.1648 & 0.265637 & $\mathrm{~A} 2$ \\
\hline & 1.4286 & 1.6087 & 0.88803 & 0.372965 & B1 \\
\hline & 1.5714 & 1.6087 & 0.97683 & 0.473989 & B2 \\
\hline & 0.57143 & 0.65217 & 0.87619 & 0.390453 & $c 1$ \\
\hline & 8.2857 & 10.609 & 0.78103 & 0.103437 & $\mathrm{C2}$ \\
\hline & 4.7143 & 4.2174 & 1.1178 & 0.332715 & D1a \\
\hline & 1.4762 & 3.6087 & 0.40906 & 0.012039 & $D 1 b$ \\
\hline & 4.0952 & 5.2609 & 0.77843 & 0.227161 & D2 \\
\hline & 2.2857 & 5 & 0.45714 & 0.000236 & E \\
\hline & 4 & 4.1304 & 0.96842 & 0.443994 & $\mathrm{~F}$ \\
\hline & 6.8095 & 5.5217 & 1.2332 & 0.175974 & $G$ \\
\hline & 1.9524 & 1.7826 & 1.0952 & 0.388278 & $\mathrm{H}$ \\
\hline & 1.381 & 2.2174 & 0.62278 & 0.083346 & I \\
\hline & 1 & 1.3478 & 0.74194 & 0.06936 & J \\
\hline & 2.9524 & 1.6522 & 1.787 & 0.498311 & K \\
\hline & 1.4762 & 1.4783 & 0.9986 & 0.223272 & L \\
\hline & 2.0476 & 1.6087 & 1.2728 & 0.363838 & M \\
\hline & 3.7619 & 3.3913 & 1.1093 & 0.390396 & $\mathrm{~N}$ \\
\hline & 1.8095 & 2 & 0.90476 & & 0 \\
\hline
\end{tabular}

Supplemental Table 2. Linkats of Essex alleles in SCN resistant and susceptible groups.

\begin{tabular}{|c|c|c|c|c|c|}
\hline & Disease Resistant & Disease Susceptible & Ratio & Probability & Linkage Groups \\
\hline \multirow[t]{20}{*}{$\bar{A}$} & 2.0952 & 2 & 1.0476 & 0.422409 & $\mathrm{~A} 1$ \\
\hline & 4.5714 & 5.3913 & 0.84793 & 0.09122 & A2 \\
\hline & 4.7143 & 4.9565 & 0.95113 & 0.34566 & B1 \\
\hline & 3.8571 & 3.6087 & 1.0688 & 0.318569 & B2 \\
\hline & 1.619 & 1.3043 & 1.2413 & 0.151028 & c1 \\
\hline & 8.1905 & 7.0435 & 1.1628 & 0.256559 & C2 \\
\hline & 6.7143 & 6.9565 & 0.96518 & 0.42173 & D1a \\
\hline & 6.0476 & 4.2609 & 1.4193 & 0.03494 & $D 1 b$ \\
\hline & 10.476 & 9.9565 & 1.0522 & 0.363385 & D2 \\
\hline & 5.6667 & 2.9565 & 1.9167 & 0.000105 & $E$ \\
\hline & 5.381 & 5.087 & 1.0578 & 0.382829 & $\mathrm{~F}$ \\
\hline & 6.8095 & 9.3043 & 0.73186 & 0.029528 & $G$ \\
\hline & 3.0476 & 2.913 & 1.0462 & 0.39344 & $\mathrm{H}$ \\
\hline & 6.8095 & 5.4783 & 1.243 & 0.044905 & I \\
\hline & 2.4762 & 2.5652 & 0.96529 & 0.434052 & $\mathrm{~J}$ \\
\hline & 5.3333 & 6.4783 & 0.82327 & 0.110741 & $\mathrm{~K}$ \\
\hline & 4.619 & 4.3478 & 1.0624 & 0.325899 & $\mathrm{~L}$ \\
\hline & 2.5238 & 3.087 & 0.81757 & 0.157233 & M \\
\hline & 5.9048 & 6.6087 & 0.89348 & 0.258952 & $\mathrm{~N}$ \\
\hline & 3.6667 & 4.1739 & 0.87847 & 0.27294 & 0 \\
\hline
\end{tabular}


Locus Interactions Underlie Seed Yield In Soybeans Resistant to Heterodera glycines i81

Supplemental Table 2. Continued

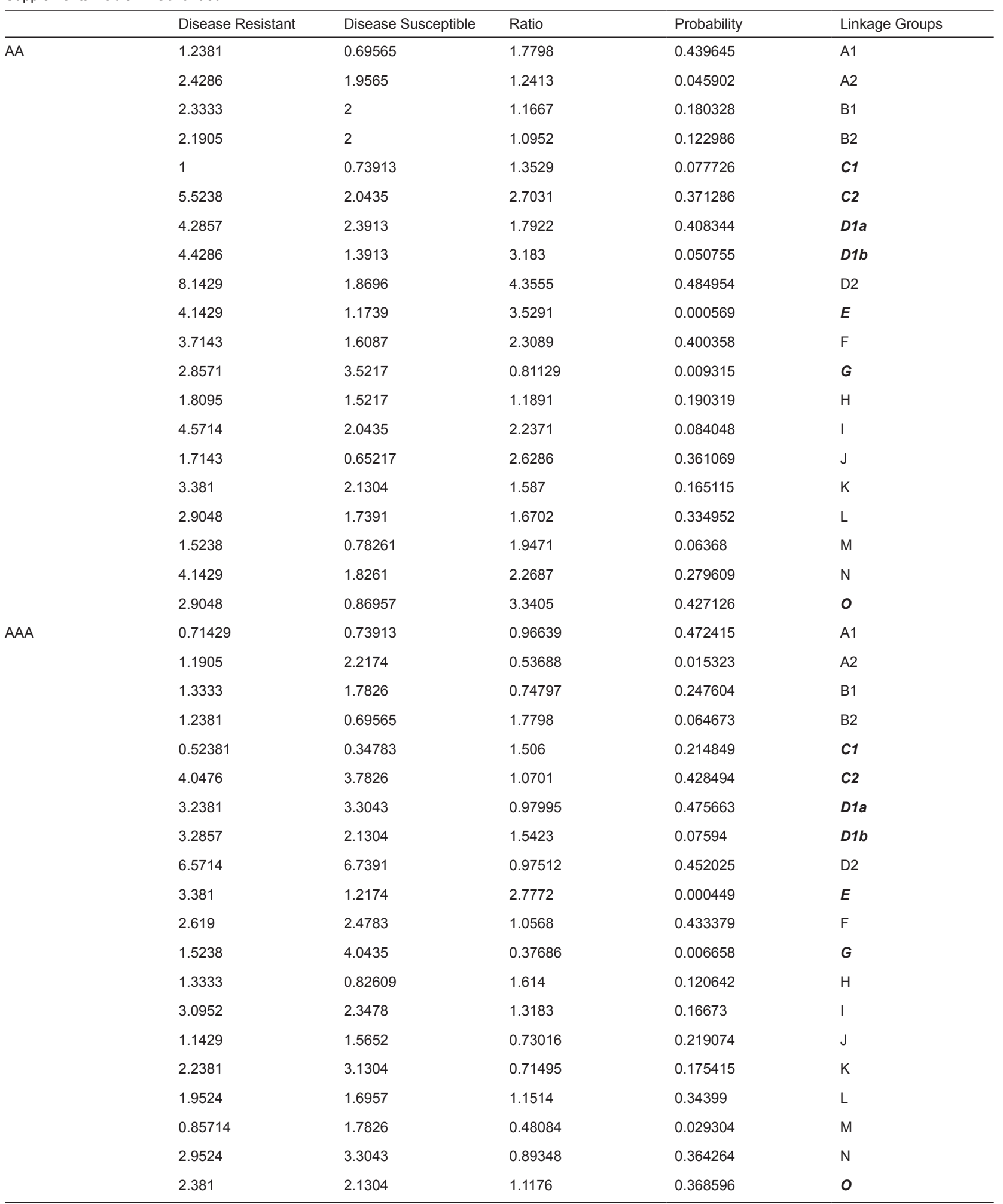


i82 Karangula et al.

Supplemental Table 3. Linkats of Essex Alleles in high and low yield groups.

\begin{tabular}{|c|c|c|c|c|c|}
\hline & Low Yield & High Yield & Ratio & Probability & Linkage Group \\
\hline \multirow[t]{21}{*}{ A } & 2.1667 & 2 & 1.0834 & 0.315483 & A1 \\
\hline & 5.4667 & 5.4 & 1.0124 & 0.067664 & A2 \\
\hline & 5.1333 & 5.0667 & 1.0131 & 0.37792 & B1 \\
\hline & 3.5333 & 4 & 0.88333 & 0.138334 & B2 \\
\hline & 1.6 & 1.2333 & 1.2973 & 0.058823 & $\mathrm{C} 1$ \\
\hline & 10.5 & 8.6 & 1.2209 & 0.299318 & $\mathrm{C} 2$ \\
\hline & 6.9333 & 7.9333 & 0.87395 & 0.102217 & D1a \\
\hline & 5.1333 & 5.4333 & 0.94478 & 0.293946 & D1b \\
\hline & 10.033 & 8.8333 & 1.1358 & 0.382622 & D2 \\
\hline & 2.6 & 2.9667 & 0.87639 & 0.448725 & E \\
\hline & 6.2667 & 6.1333 & 1.0218 & 0.349282 & $\mathrm{~F}$ \\
\hline & 11.1 & 9.7667 & 1.1365 & 0.376234 & G \\
\hline & 3.3333 & 3 & 1.1111 & 0.141052 & $\mathrm{H}$ \\
\hline & 6.4667 & 4.8667 & 1.3288 & 0.054894 & $I$ \\
\hline & 3.0667 & 2.5667 & 1.1948 & 0.140526 & $\mathrm{~J}$ \\
\hline & 4.5 & 7.2333 & 0.62212 & 1.16E-05 & $K$ \\
\hline & 3.9333 & 4.6333 & 0.84892 & 0.065702 & L \\
\hline & 2.7667 & 3.1667 & 0.87369 & 0.166634 & M \\
\hline & 6.7667 & 6.9333 & 0.97597 & 0.218238 & $\mathrm{~N}$ \\
\hline & 4.9 & 4.4 & 1.1136 & 0.315148 & $\mathrm{O}$ \\
\hline & 5.31 & 5.2083 & 1.02843 & & Mean \\
\hline \multirow[t]{21}{*}{ AA } & 1.0952 & 0.80952 & 1.3529 & 0.221378 & A1 \\
\hline & 3.381 & 2.619 & 1.291 & 0.10773 & A2 \\
\hline & 2.7619 & 3.5238 & 0.78378 & 0.1583 & B1 \\
\hline & 1.9048 & 1.9524 & 0.97562 & 0.468098 & B2 \\
\hline & 1.1429 & 0.71429 & 1.6001 & 0.108101 & $\mathrm{C} 1$ \\
\hline & 8.381 & 6.619 & 1.2662 & 0.172517 & $\mathrm{C} 2$ \\
\hline & 4.7143 & 5.3333 & 0.88394 & 0.313992 & D1a \\
\hline & 3.8095 & 4.7143 & 0.80807 & 0.199123 & D1b \\
\hline & 7.619 & 6.1429 & 1.2403 & 0.16879 & D2 \\
\hline & 1.7143 & 1.7143 & 1 & 0.5 & E \\
\hline & 4.8571 & 3.9524 & 1.2289 & 0.215976 & $\mathrm{~F}$ \\
\hline & 7.8571 & 7 & 1.1224 & 0.305542 & G \\
\hline & 2.0952 & 1.619 & 1.2941 & 0.221589 & $\mathrm{H}$ \\
\hline & 4.4286 & 2.9524 & 1.5 & 0.032979 & $I$ \\
\hline & 2.2381 & 2.2857 & 0.97917 & 0.468454 & $\mathrm{~J}$ \\
\hline & 2.8571 & 5.1429 & 0.55554 & 0.009804 & $K$ \\
\hline & 2.2381 & 2.9524 & 0.75806 & 0.178496 & L \\
\hline & 2.381 & 2.2857 & 1.0417 & 0.436078 & M \\
\hline & 5.1905 & 5.0952 & 1.0187 & 0.469325 & $\mathrm{~N}$ \\
\hline & 2.4762 & 2.7619 & 0.89656 & 0.317056 & $\mathrm{O}$ \\
\hline & 3.6571 & 3.50952 & 1.07985 & & Mean \\
\hline
\end{tabular}


Locus Interactions Underlie Seed Yield In Soybeans Resistant to Heterodera glycines i83

Supplemental Table 3. Continued

\begin{tabular}{|c|c|c|c|c|c|}
\hline & Low Yield & High Yield & Ratio & Probability & Linkage Group \\
\hline \multirow[t]{20}{*}{ AAA } & 0.83333 & 0.6 & 1.3889 & 0.227018 & A1 \\
\hline & 2.1667 & 2.3 & 0.94204 & 0.395092 & $\mathrm{~A} 2$ \\
\hline & 1.9333 & 2 & 0.96665 & 0.460807 & B1 \\
\hline & 1.1 & 1.0667 & 1.0312 & 0.465053 & B2 \\
\hline & 0.73333 & 0.3 & 2.4444 & 0.026908 & $\mathrm{C} 1$ \\
\hline & 5.7667 & 5.0667 & 1.1382 & 0.304805 & $\mathrm{C} 2$ \\
\hline & 3.5 & 4.2333 & 0.82678 & 0.211233 & D1a \\
\hline & 2.5 & 3.1333 & 0.79788 & 0.209991 & D1b \\
\hline & 6.6333 & 5.4 & 1.2284 & 0.14822 & D2 \\
\hline & 1.3 & 1.6 & 0.8125 & 0.253408 & $E$ \\
\hline & 3.4333 & 3.4333 & 1 & 0.5 & $\mathrm{~F}$ \\
\hline & 1.5667 & 1.2 & 1.3056 & 0.207928 & $\mathrm{H}$ \\
\hline & 3.1 & 1.8333 & 1.6909 & 0.018296 & $I$ \\
\hline & 1.7333 & 1.5667 & 1.1063 & 0.359631 & $\mathrm{~J}$ \\
\hline & 1.6667 & 3.9333 & 0.42374 & 0.002573 & $K$ \\
\hline & 1.0333 & 2.0667 & 0.49998 & 0.028137 & $\mathrm{~L}$ \\
\hline & 1.4333 & 1.5333 & 0.93478 & 0.407889 & M \\
\hline & 3.5667 & 4.4 & 0.81061 & 0.186029 & $\mathrm{~N}$ \\
\hline & 2.6333 & 2.4667 & 1.0675 & 0.396604 & $\mathrm{O}$ \\
\hline & 2.68999 & 2.6483 & & & Mean \\
\hline
\end{tabular}

Supplemental Table 4. Linkats of Forrest alleles in high and low yield groups.

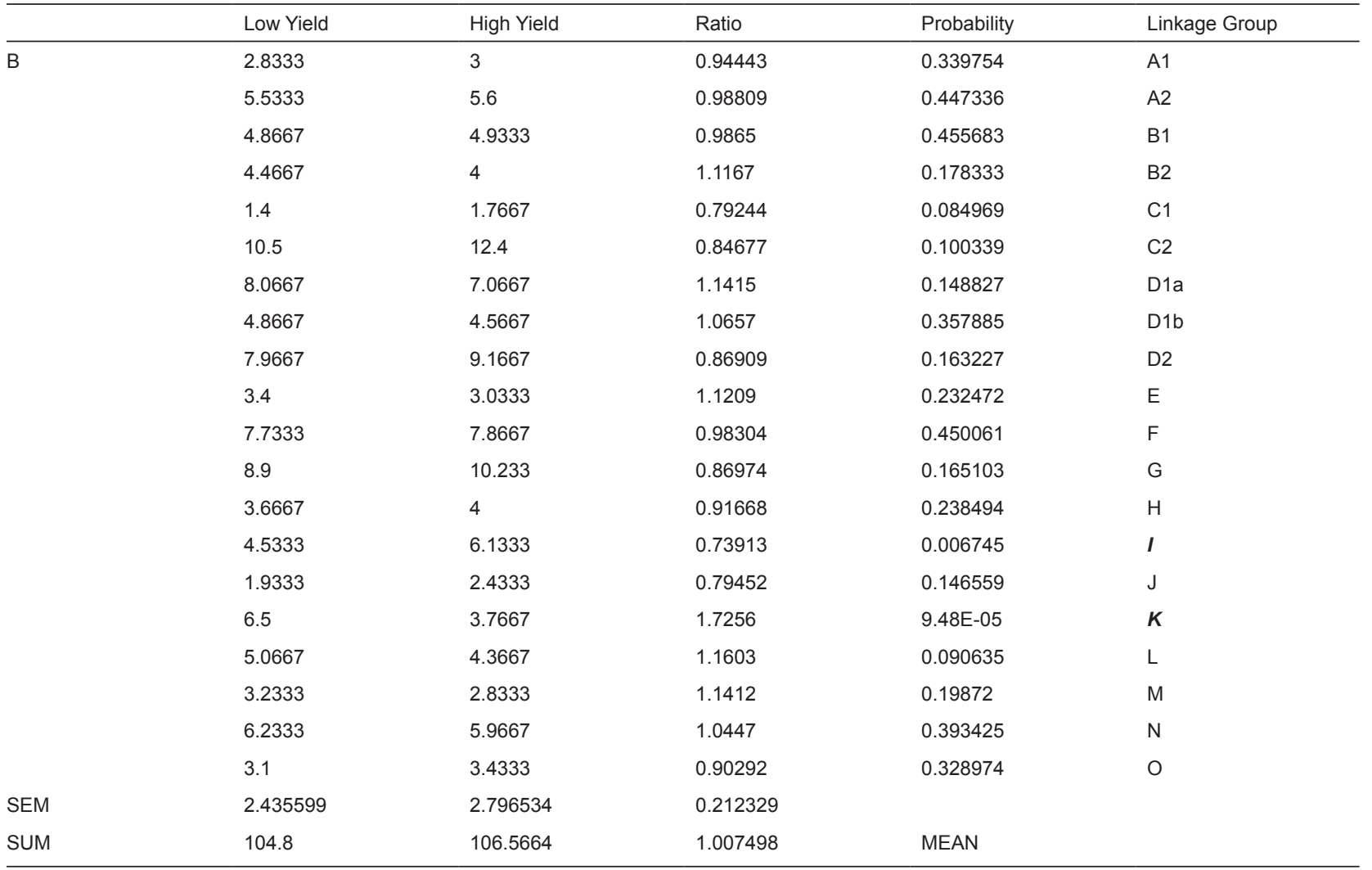


i84 Karangula et al.

Supplemental Table 4. Continued

\begin{tabular}{|c|c|c|c|c|c|}
\hline & Low Yield & High Yield & Ratio & Probability & Linkage Group \\
\hline \multirow[t]{20}{*}{ BB } & 1.9 & 1.8667 & 1.0178 & 0.471703 & \\
\hline & 3.4667 & 3.7 & 0.93695 & 0.340583 & \\
\hline & 2.8667 & 2.8 & 1.0238 & 0.45589 & \\
\hline & 2.8 & 2.3333 & 1.2 & 0.218565 & \\
\hline & 0.6 & 1.1 & 0.54545 & 0.035078 & \\
\hline & 8.0333 & 10 & 0.80333 & 0.095882 & \\
\hline & 5.6333 & 4.7667 & 1.1818 & 0.188766 & \\
\hline & 3.2 & 3.1333 & 1.0213 & 0.468363 & \\
\hline & 6.2 & 7.1 & 0.87324 & 0.238981 & \\
\hline & 2.3667 & 2.2333 & 1.0597 & 0.411216 & \\
\hline & 5.9667 & 6.0333 & 0.98896 & 0.473981 & \\
\hline & 5.4333 & 6.9 & 0.78743 & 0.133041 & \\
\hline & 2.2667 & 2.8 & 0.80954 & 0.146998 & \\
\hline & 2.2667 & 4.0333 & 0.562 & 0.00263 & \\
\hline & 1.4333 & 1.7333 & 0.82692 & 0.244333 & \\
\hline & 4.8333 & 1.9667 & 2.4576 & $2.98 \mathrm{E}-05$ & \\
\hline & 3.0333 & 2.5 & 1.2133 & 0.154261 & \\
\hline & 2.4333 & 2.0333 & 1.1967 & 0.206271 & \\
\hline & 4.1 & 4.3 & 0.95349 & 0.418899 & \\
\hline & 1.9333 & 2.1667 & 0.89228 & 0.370876 & \\
\hline SEM & 1.901279 & 2.271715 & 0.388184 & & \\
\hline SUM & 70.7666 & 73.4999 & 1.01758 & MEAN & \\
\hline \multirow[t]{20}{*}{ BBB } & 1.2667 & 1.2 & 1.0556 & 0.430955 & \\
\hline & 2.4667 & 2.5667 & 0.96104 & 0.426163 & \\
\hline & 1.8333 & 1.5 & 1.2222 & 0.257691 & \\
\hline & 2 & 1.6 & 1.25 & 0.224322 & \\
\hline & 0.3 & 0.76667 & 0.3913 & 0.018609 & \\
\hline & 6.5 & 8.3333 & 0.78 & 0.105269 & \\
\hline & 4.1667 & 3.4667 & 1.2019 & 0.211313 & \\
\hline & 2.3333 & 2.3667 & 0.98589 & 0.482938 & \\
\hline & 5 & 5.9333 & 0.8427 & 0.22218 & \\
\hline & 1.9667 & 2 & 0.98335 & 0.478212 & \\
\hline & 4.5667 & 4.4 & 1.0379 & 0.42911 & \\
\hline & 3.7 & 5.5333 & 0.66868 & 0.060731 & \\
\hline & 1.5667 & 1.9667 & 0.79661 & 0.213927 & \\
\hline & 1.1667 & 2.7667 & 0.42169 & 0.002201 & \\
\hline & 1.0333 & 1.1667 & 0.88566 & 0.367227 & \\
\hline & 3.5333 & 1.2 & 2.9444 & 0.000314 & \\
\hline & 1.7333 & 1.3667 & 1.2682 & 0.202926 & \\
\hline & 1.9667 & 1.4667 & 1.3409 & 0.146063 & \\
\hline & 2.8 & 3.1333 & 0.89363 & 0.350178 & \\
\hline & 1.5333 & 1.6333 & 0.93877 & 0.5 & \\
\hline SEM & 1.956247 & 0.51542 & 0.168429 & & \\
\hline MEAN & & & 1.043521 & & \\
\hline
\end{tabular}




\section{Further Reading}

Caister Academic Press is a leading academic publisher of advanced texts in microbiology, molecular biology and medical research. Full details of all our publications at caister.com

- MALDI-TOF Mass Spectrometry in Microbiology Edited by: M Kostrzewa, S Schubert (2016) www.caister.com/malditof

- Aspergillus and Penicillium in the Post-genomic Era Edited by: RP Vries, IB Gelber, MR Andersen (2016) www.caister.com/aspergillus2

- The Bacteriocins: Current Knowledge and Future Prospects Edited by: RL Dorit, SM Roy, MA Riley (2016)

www.caister.com/bacteriocins

- Omics in Plant Disease Resistance Edited by: V Bhadauria (2016) www.caister.com/opd

- Acidophiles: Life in Extremely Acidic Environments Edited by: R Quatrini, DB Johnson (2016) www.caister.com/acidophiles

- Climate Change and Microbial Ecology: Current Research and Future Trend

Edited by: J Marxsen (2016)

www.caister.com/climate

- Biofilms in Bioremediation: Current Research and Emerging Technologies

Edited by: G Lear (2016)

www.caister.com/biorem

- Microalgae: Current Research and Applications Edited by: MN Tsaloglou (2016) www.caister.com/microalgae

- Gas Plasma Sterilization in Microbiology: Theory, Applications, Pitfalls and New Perspectives Edited by: H Shintani, A Sakudo (2016) www.caister.com/gasplasma

- Virus Evolution: Current Research and Future Directions Edited by: SC Weaver, M Denison, M Roossinck, et al. (2016) www.caister.com/virusevol

- Arboviruses: Molecular Biology, Evolution and Control Edited by: N Vasilakis, DJ Gubler (2016) www.caister.com/arbo

- Shigella: Molecular and Cellular Biology Edited by: WD Picking, WL Picking (2016) www.caister.com/shigella

-Aquatic Biofilms: Ecology, Water Quality and Wastewater Treatment

Edited by: AM Romaní, H Guasch, MD Balaguer (2016)

www.caister.com/aquaticbiofilms

- Alphaviruses: Current Biology

Edited by: S Mahalingam, L Herrero, B Herring (2016)

www.caister.com/alpha

- Thermophilic Microorganisms

Edited by: F Li (2015)

www.caister.com/thermophile
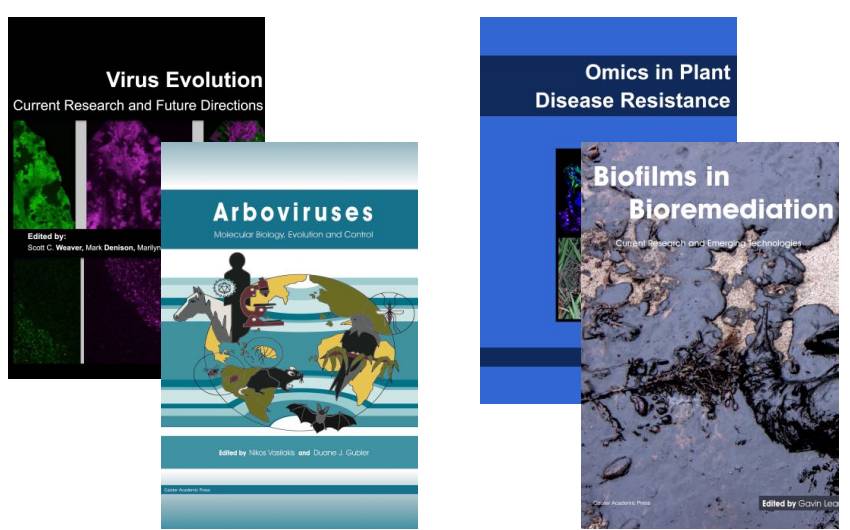
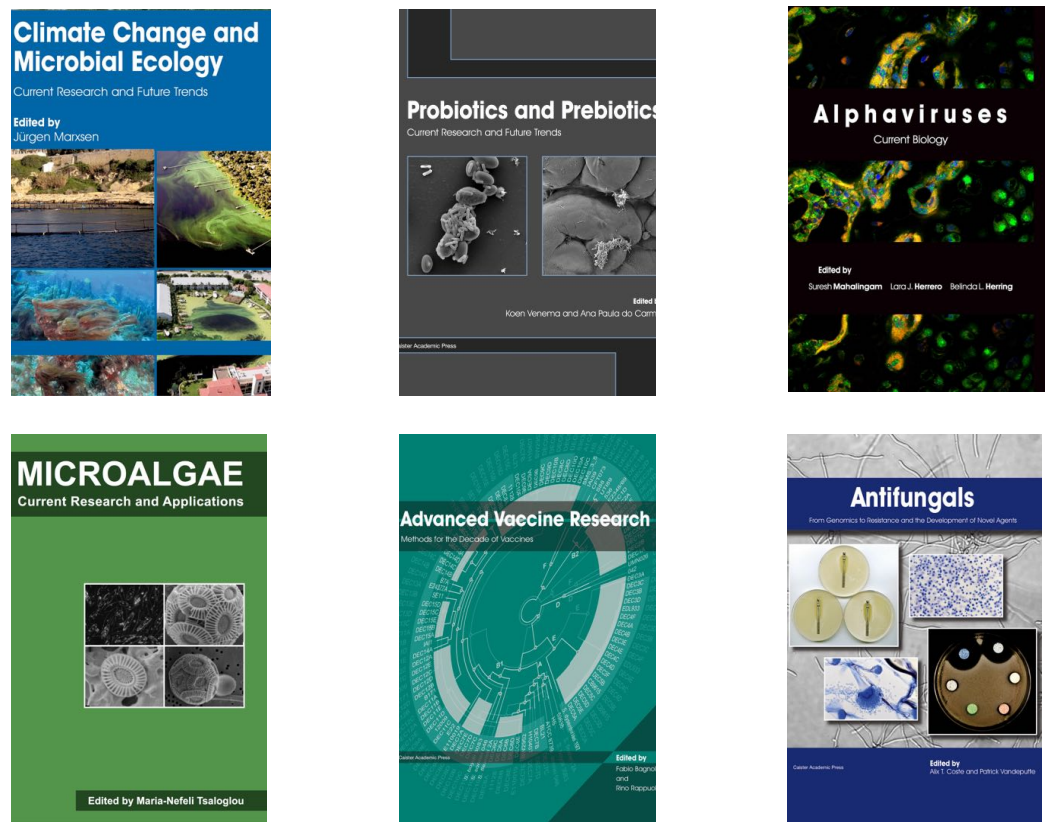

- Flow Cytometry in Microbiology: Technology and Applications Edited by: MG Wilkinson (2015) www.caister.com/flow

- Probiotics and Prebiotics: Current Research and Future Trends Edited by: K Venema, AP Carmo (2015) www.caister.com/probiotics

- Epigenetics: Current Research and Emerging Trends Edited by: BP Chadwick (2015) www.caister.com/epigenetics2015

- Corynebacterium glutamicum: From Systems Biology to Biotechnological Applications

Edited by: A Burkovski (2015)

www.caister.com/cory2

- Advanced Vaccine Research Methods for the Decade of Vaccines

Edited by: F Bagnoli, R Rappuoli (2015)

www.caister.com/vaccines

- Antifungals: From Genomics to Resistance and the Development of Novel Agents

Edited by: AT Coste, P Vandeputte (2015)

www.caister.com/antifungals

- Bacteria-Plant Interactions: Advanced Research and Future Trends Edited by: J Murillo, BA Vinatzer, RW Jackson, et al. (2015) www.caister.com/bacteria-plant

\section{- Aeromonas}

Edited by: J Graf (2015)

www.caister.com/aeromonas

- Antibiotics: Current Innovations and Future Trends

Edited by: S Sánchez, AL Demain (2015)

www.caister.com/antibiotics

- Leishmania: Current Biology and Contro Edited by: S Adak, R Datta (2015) www.caister.com/leish2

- Acanthamoeba: Biology and Pathogenesis (2nd edition) Author: NA Khan (2015)

www.caister.com/acanthamoeba2

- Microarrays: Current Technology, Innovations and Applications Edited by: Z He (2014)

www.caister.com/microarrays2

- Metagenomics of the Microbial Nitrogen Cycle: Theory, Methods and Applications

Edited by: D Marco (2014)

www.caister.com/n2 